\title{
Market Reaction to Second-Hand News: Attention-Grabbing or Information Dissemination?
}

\author{
Enrico Maria Cervellati, ${ }^{*}$ Riccardo Ferretti, ${ }^{\dagger}$ Pierpaolo Pattitoni ${ }^{*}$
}

\begin{abstract}
This paper deals with a long standing issue in finance: weather the market reaction to second-hand information is due to price pressure or dissemination. We take an attention-grabbing perspective as a particular form of price pressure in analysing the market reaction to the dissemination of analysts' recommendations through the press. This perspective allows predicting an asymmetric market reaction to "buy" and "sell" advises, already detected in few other empirical studies, otherwise difficult to rationalize within the standard price pressure hypothesis. In particular, we analyse the content of a column that appears weekly in the most important Italian financial newspaper and presents past information and analysts' recommendations on listed companies, finding an asymmetric price and volume reaction. Contrary to previous evidence, we document a positive relation between the number of analysts quoted in the column and the price (volume) increase associated to positive recommendations. Since the weekly columns simply attract the attention of investors with no additional new information, it is natural to observe a greater reaction for the most "glamour" stocks (i.e. the stocks analysts follow mostly).
\end{abstract}

\footnotetext{
* University of Bologna, Department of Management, via Capo di Lucca, 34, 40126 Bologna, Italy. Emails: enrico.cervellati@unibo.it; pierpaolo.pattitoni@unibo.it. Tel: +39 051 2098103; fax: +39 051246411.

${ }^{\dagger}$ University of Modena and Reggio Emilia and Cefin, Via A. Allegri, 9 - 42121 Reggio Emilia. Tel. +390522523228. Email: riccardo.ferretti@unimore.it. Reference author.
} 


\section{Introduction}

The financial market efficiency literature has devoted some attention to the stock market reaction to the dissemination of analysts' recommendations through printed media. In an efficient market, the publication of recommendations previously issued should be considered as conveying second-hand information, with no consequences on prices and volumes. The empirical evidence of the last thirty years, however, tells a different story: the publication of analysts' recommendations induces abnormal movements in stock prices and in the trading activity. ${ }^{1}$

This puzzling reaction has been fundamentally explained in two competing ways. According to the so-called Information Dissemination Hypothesis (IDH) [Table A.1], prices and volumes adjust because the publication of analysts' recommendations is real news: the trades by analysts' clients would not be enough to fully disseminate its information content. The Price Pressure Hypothesis (PPH) [Table A.2], instead, states that these adjustments are due to the irrational behaviour of naïve investors. The key disagreement regards the empirical evidence supporting the two competing theories with regard to the price reversal in the post-publication period: absent or partial in the IDH while present in the $\mathrm{PPH}^{2}$

The IDH studies are mainly based on two Wall Street Journal columns: the daily "Heard on the Street" (HS) and the monthly "Dartboard". In both cases, "buy" and "sell" recommendations are quoted, but the small number of "sell" recommendations allows a separate analysis only for the monthly "HS" columns. "Buy" and "sell" recommendations are accompanied, on average, by significant abnormal returns (positive and negative, respectively) on the publication day. These symmetric price movements are in line with a rational reaction to good and bad news. However, there are doubts that analysts' recommendations discussed in the "HS" column have the nature of second-hand information (Lloyd-Davies and Canes, 1978), but also that they report rumours about changes in the firms' fundamentals (Pound and Zeckhouser, 1990; Beneish, 1991; Pruitt et al., 2000). In some circumstances, the stock market completely anticipates the information content of analysts' recommendations mentioned in the press. Pound and Zeckhouser (1990), focusing on takeover rumours, find no abnormal return on the publication day in the "HS" column and a price

\footnotetext{
${ }^{1}$ The empirical studies listed in tables A.1 and A.2 in the Appendix analyse printed columns based on explicit or implicit analysts' recommendations. Other studies consider the publication of columnists' recommendations/rumours (Lee, 1986; Ferreira and Smith, 1999; Muradoğlu and Yazici, 2002; Kiymaz, 2002) or TV broadcasted analysts' recommendations (Pari, 1987; Ferreira and Smith, 2003).

${ }^{2}$ Pruitt et al. (2000) do not observe a reversal in prices, but they find that the positive abnormal returns on the announcement day and in the following days are related to smaller investors' buying.
} 
run-up in the previous month. Beneish (1991) finds no price reaction on the publication day, ${ }^{3}$ but significant abnormal returns in the two previous days when "HS" discusses a single firm. A possible explanation is that the consensus in the "HS" column is formed from analysts' recommendations. An alternative one relates to the analysts' incentives to submit information to "HS" before disseminating it to their private clients. This could be the case if the analysts trade on the firms they cover or if they are trying to increase their reputation and visibility through press coverage. However, there are costs in terms of reputation (and potentially also in terms of employment) associated with the possibility that the clients would find out this unfair behaviour (Beneish, 1991).

The PPH studies essentially cover a couple of columns as well: the weekly Business Week's "Inside Wall Street" and the monthly Wall Street Journal's "Dartboard" (also used in IDH studies). The evidence mainly regards "buy" recommendations. The few studies that also investigate "sell" recommendations (Sant and Zaman, 1996; Lidén, 2007) ${ }^{4}$ show a significant price increase for positive advices and no abnormal returns for negative advises; this asymmetric price reaction is difficult to rationalize within the PPH since it is not clear why naïve investors should irrationally react to "buy" recommendations while disregarding "sell" recommendations. Moreover, Albert and Smaby (1996) document that the post-publication price reversal shown in the PPH studies concerning "Dartboard" has a methodological explanation: most stocks recommended by analysts in the column tend to be momentum stocks; therefore, a pre-event estimate of the market model generates inflated alpha values that bias upward the post-event normal return, leading to negative abnormal returns in the days after the publication.

In short, both the IDH and the PPH reveal some empirical weaknesses: the doubts on the secondhand nature of "HS" recommendations for the former; the methodological bias behind the postpublication price reversal and the puzzling asymmetric price reaction for the latter.

The post-publication price performance, however, is not the sole way to evaluate the degree of irrationality in the market reaction to second-hand information. Another possibility is to look for the attention-grabbing potential of printed columns disseminating analysts' recommendations. Secondhand information may increase attention focused on the company, putting price pressure on its stocks (Trahan and Bolster, 1995). The Attention-Grabbing Hypothesis (AGH) states that individual investors are net buyers of attention-grabbing stocks (Barber and Odean, 2008). Human beings have

\footnotetext{
${ }^{3}$ For the whole sample, however, the price reaction on the publication day is statistically different from zero.

4 A third study exists (Trahan and Bolster, 1995) but the sample of "sell" recommendation is limited to eleven observations.
} 
bounded rationality; therefore individual investors face a huge search problem in buying decisions: there are thousands of stocks in the investment set from which to choose. The selling decisions, instead, are much easier since the set is limited to the stocks already included in the portfolio, given that retail investors usually do not sell short. To simplify the search problem, investors rely on the "availability heuristic" (Tversky and Kahneman, 1974) and confine the investment set to the stocks that capture their attention. Once attention has reduced the choice set, the stocks to buy are picked up following individual preferences, i.e. investors do not buy all the attention-grabbing stocks (Odean, 1999). In this perspective, the AGH predicts an asymmetric market reaction to "buy" and "sell" recommendations on the publication day: positive and significant abnormal returns and volumes for "buy" advices, insignificant abnormal returns and volumes for "sell" advices.

Barber and Odean (2008) study the buying and selling behaviour of individual and institutional investors in days on which an event drives investors' attention toward a particular firm's stock. These days are identified by looking at three attention-grabbing events: i) a stock's unusual daily trading volume; ii) an extreme stock's return in the previous day; iii) the firm mentioned in the news of the day. In line with their hypothesis, they find that individual investors tend to be net buyers on high volume days, following both extremely negative and extremely positive one-day returns, and when stocks are in the news. Instead, professional investors' buying behaviour is not influenced by attention. The news metric (whether a stock appears in the news of the day) proves to be the least informative proxy of attention, but apparently because of the available data that do not allow measuring the salience of news coverage. The authors also find that attention-driven buying is as strong for large capitalization stocks as for small stocks. Since many pricing anomalies are greater for small stocks than for large stocks, they argue that common psychological trading biases may result in different price reactions depending on firms' capitalization. The focus of the Barber and Odean's paper is on investors' behaviour, not on the pricing impact of the behaviour itself. In this paper, we verify the attention-grabbing power of particular news coverage through the analysis of its price and trading volume consequences. The aim is to deepen the understanding of the attention-grabbing mechanism, especially the role played by the size and the popularity of the mentioned firms. We also test whether the attention-grabbing impact on stocks' prices is totally irrational or if it contributes to market efficiency by spreading public information about firms' fundamentals. As far as we know, our paper is the first one looking at the stock price reaction to the dissemination of analysts' recommendations through printed media from an attention-grabbing perspective. In particular, we contribute to the literature proposing and testing the hypothesis of an asymmetric price reaction. These elements differentiate our paper to others that test the AGH 
focusing on different events. Seasholes and Wu (2004) find that unsophisticated investors are net buyers of stocks that the day before hit their daily upper price limit; they document a transitory impact on prices with reversion to pre-event levels within ten trading days. Fehle, Tsyplakov and Zdorovtsov (2005) study the attention-grabbing potential of the TV commercials in 19 Super Bowl broadcasts and show that recognisable companies (with a number of ads greater than the sample mean) experience a positive price reaction which persists in the 20-day post-event period.

Our potential attention-grabbing event is the weekly column "The Stock of the Week" which appears on Plus, the weekly investment magazine edited by Il Sole 24 Ore, the Italian top financial newspaper. Plus is ready for the press on Thursday evening, but it is only published two days later, on Saturday (along with the main newspaper). These Saturday's columns share the same features: author, page layout, dimension (two pages), position inside the magazine and type of information provided (balance sheet and income statement data, managers' outlook, past stock price performance, and analysts' recommendations). Often, but not always, the column also provides analysts' consensus forecast and recommendation, as well as expected price-earnings ratios of comparable companies. The common characteristics make our events homogeneous in terms of the attention-grabbing power except for the spin of analysts' recommendations that can be positive, neutral or negative. The column does not contain genuine news since all the data presented and information provided are already of public domain. Thus, they should be already known, at least to professional investors. However, we find a positive abnormal market reaction to the publication of the column when analysts grade the stock as a good opportunity, suggesting that the second-hand information there provided affect irrationally the buying decision of individual investors. This evidence supports the AGH, and shows that attention-grabbing is able to induce a significant and asymmetric market reaction. The finding that the price surge is positively related to the popularity of the stock (proxied by the number of quoted analysts) is an additional support to the AGH.

\section{Data and methodology}

\subsection{Sample selection and data}

We collected all the 165 "Stock of the Week" columns published from January $2^{\text {nd }}, 2005$ to June $30^{\text {th }}, 2009$ devoted to a domestic company listed in the Italian Stock Exchange. In particular, we analyze companies listed in two major markets managed by Borsa Italiana: MTA (Mercato Telematico Azionario) and Expandi. MTA was Borsa Italiana's electronic market on which stocks, convertible bonds, warrants and option rights were traded. MTA was the main Italian stock market. 
Expandi used to be the market dedicated to smaller size companies. The two markets had different listing requirements and partially different trading rules. On September 19 2005, a new market structure was introduced. In particular, within MTA, companies were divided into three segments: Blue Chip, Star and Standard. Blue Chip is the segment dedicated to companies with a capitalisation of over 1 billion euro. Standard is the market for all companies with a capitalisation between 1 billion and 40 million euro. Star is the segment for companies with a capitalisation of less than 1 billion euro which voluntarily comply with strict requirements on liquidity, transparency and corporate governance. MTA and Expandi merged on June 15, 2009. ${ }^{5}$

The "Stock of the Week" columns covering foreign companies are excluded from the sample since it is unrealistic to think that foreign investors read the newspaper (that is written in Italian) looking for news about non Italian companies. Therefore, the column should not affect the buying and selling decisions of foreign investors regarding non Italian listed companies. Furthermore, Italian retail investors tend to mainly hold Italian stocks and trade them in the domestic market (Felettigh and Monti, 2008). Thus, their trading is not expected to have relevant influences on prices and volumes in foreign stock markets.

The final sample includes 154 observations after removing nine columns concerning companies with a short listing history (less than 130 trading days before the column's date), a column dealing with two companies at once, and one column distributed with some delay due to a strike. For each column we collected the following data: a) name of the company analysed; b) stock price, number of traded and outstanding shares on a daily basis from 255 trading days before and ten trading days after the event day (source: DataStream); c) market segment of listing as of the "event day" (source: Borsa Italiana website); d) company's sector of activity (source: Borsa Italiana web site); e) company size in terms of book value and capitalization; f) spin of the analysts' recommendations reported in the column (positive vs. neutral and negative); g) consensus earnings forecasts and recommendation reported in the column; h) number of analysts whose recommendations are reported in the column.

\subsection{Sample composition and descriptive statistics}

Table 1 shows the composition and the time distribution of our sample in terms of number of events, number of companies, availability of analysts' consensus and detailed recommendations, and economic sectors.

\footnotetext{
${ }^{5} \mathrm{Up}$ to the merger with MTA, we include in the Standard group all the companies listed on the Expandi (eight observations).
} 
Table 1 - Sample composition

\begin{tabular}{|c|c|c|c|c|c|c|c|c|c|c|c|c|}
\hline & \multicolumn{2}{|c|}{ Total } & \multicolumn{2}{|c|}{2005} & \multicolumn{2}{|c|}{2006} & \multicolumn{2}{|c|}{2007} & \multicolumn{2}{|c|}{2008} & \multicolumn{2}{|c|}{ 2009.1H } \\
\hline & Obs & $\%$ & Obs & $\%$ & Obs & $\%$ & Obs & $\%$ & Obs & $\%$ & Obs & $\%$ \\
\hline Columns & 154 & 100 & 24 & 15.58 & 27 & 17.53 & 34 & 22.08 & 45 & 29.22 & 24 & 15.58 \\
\hline \multicolumn{13}{|c|}{ Columns by stock's market segment } \\
\hline Blue Chips & 19 & 12.34 & 2 & 8.33 & 6 & 22.22 & 6 & 17.65 & 3 & 6.67 & 2 & 8.33 \\
\hline Star & 80 & 51.95 & 13 & 54.17 & 11 & 40.74 & 18 & 52.94 & 27 & 60.00 & 11 & 45.83 \\
\hline Standard \& Expandi & 55 & 35.71 & 9 & 37.50 & 10 & 37.04 & 10 & 29.41 & 15 & 33.33 & 11 & 45.83 \\
\hline Total & 154 & 100 & 24 & 100 & 27 & 100 & 34 & 100 & 45 & 100 & 24 & 100 \\
\hline \multicolumn{13}{|c|}{ Columns by consensus recommendation } \\
\hline Positive & 72 & 46.75 & 2 & 8.33 & 19 & 70.37 & 22 & 64.71 & 17 & 37.78 & 12 & 50.00 \\
\hline Neutral and negative & 31 & 20.13 & 1 & 4.17 & 6 & 22.22 & 8 & 23.53 & 10 & 22.22 & 6 & 25.00 \\
\hline No consensus & 51 & 33.12 & 21 & 87.50 & 2 & 7.41 & 4 & 11.76 & 18 & 40.00 & 6 & 25.00 \\
\hline Total & 154 & 100 & 24 & 100 & 27 & 100 & 34 & 100 & 45 & 100 & 24 & 100 \\
\hline \multicolumn{13}{|c|}{ Columns by analyst's recommendation } \\
\hline Positive & 92 & 59.74 & 11 & 45.83 & 18 & 66.67 & 22 & 64.71 & 26 & 57.78 & 15 & 62.50 \\
\hline Neutral and negative & 52 & 33.77 & 8 & 33.33 & 7 & 25.93 & 11 & 32.35 & 18 & 40.00 & 8 & 33.33 \\
\hline No recommendations & 10 & 6.49 & 5 & 20.83 & 2 & 7.41 & 1 & 2.94 & 1 & 2.22 & 1 & 4.17 \\
\hline Total & 154 & 100 & 24 & 100 & 27 & 100 & 34 & 100 & 45 & 100 & 24 & 100 \\
\hline \multicolumn{13}{|c|}{ Columns by company's economic sector } \\
\hline Industrial Goods \& Services & 35 & 22.73 & 5 & 20.83 & 8 & 29.63 & 9 & 26.47 & 9 & 20.00 & 4 & 16.67 \\
\hline Banks & 20 & 12.99 & 4 & 16.67 & 4 & 14.81 & 2 & 5.88 & 6 & 13.33 & 4 & 16.67 \\
\hline Financial Services & 18 & 11.69 & 3 & 12.50 & 4 & 14.81 & 3 & 8.82 & 5 & 11.11 & 3 & 12.50 \\
\hline Construction \& Materials & 16 & 10.39 & 2 & 8.33 & 3 & 11.11 & 3 & 8.82 & 4 & 8.89 & 4 & 16.67 \\
\hline Personal \& Household Goods & 11 & 7.14 & 1 & 4.17 & 2 & 7.41 & 3 & 8.82 & 3 & 6.67 & 2 & 8.33 \\
\hline Technology & 11 & 7.14 & 2 & 8.33 & 1 & 3.70 & 4 & 11.76 & 3 & 6.67 & 1 & 4.17 \\
\hline Automobiles \& Parts & 10 & 6.49 & 2 & 8.33 & 1 & 3.70 & 3 & 8.82 & 4 & 8.89 & 0 & 0.00 \\
\hline Utilities & 7 & 4.55 & 2 & 8.33 & 0 & 0.00 & 1 & 2.94 & 3 & 6.67 & 1 & 4.17 \\
\hline Media & 5 & 3.25 & 1 & 4.17 & 1 & 3.70 & 0 & 0.00 & 2 & 4.44 & 1 & 4.17 \\
\hline Health Care & 5 & 3.25 & 2 & 8.33 & 0 & 0.00 & 1 & 2.94 & 2 & 4.44 & 0 & 0.00 \\
\hline Retail & 5 & 3.25 & 0 & 0.00 & 1 & 3.70 & 1 & 2.94 & 2 & 4.44 & 1 & 4.17 \\
\hline Chemicals & 4 & 2.60 & 0 & 0.00 & 1 & 3.70 & 2 & 5.88 & 0 & 0.00 & 1 & 4.17 \\
\hline Insurance & 2 & 1.30 & 0 & 0.00 & 0 & 0.00 & 1 & 2.94 & 1 & 2.22 & 0 & 0.00 \\
\hline Oil \& Gas & 2 & 1.30 & 0 & 0.00 & 0 & 0.00 & 0 & 0.00 & 1 & 2.22 & 1 & 4.17 \\
\hline Basic Resources & 1 & 0.65 & 0 & 0.00 & 0 & 0.00 & 1 & 2.94 & 0 & 0.00 & 0 & 0.00 \\
\hline Food \& Beverage & 1 & 0.65 & 0 & 0.00 & 1 & 3.70 & 0 & 0.00 & 0 & 0.00 & 0 & 0.00 \\
\hline Telecommunications & 1 & 0.65 & 0 & 0.00 & 0 & 0.00 & 0 & 0.00 & 0 & 0.00 & 1 & 4.17 \\
\hline Total & 154 & 100 & 24 & 100 & 27 & 100 & 34 & 100 & 45 & 100 & 24 & 100 \\
\hline
\end{tabular}

We selected the time period to have bull and bear stock market cycles of almost equivalent length. ${ }^{6}$ Our events are not well uniformly distributed over time since they concentrate in the period 2007-

\footnotetext{
${ }^{6}$ The turning points from bull to bear and from bear to bull are, respectively, May 31, 2007 and March 11, 2009.
} 
2008 (51\% of the sample). This is due to the number of columns covering foreign companies, particularly high in the first two years of our sample. Nonetheless, exactly half of the events (77) take place during the bear market cycle (June 1, 2007 - March 10, 2009) and half during the bull market period.

The 154 columns examined cover 86 firms since some companies are analysed more than once, but never in the same year: four companies are the "Stock of the Week" four times; 13 companies three times; 30 companies two times, and 39 companies one time.

Most events are related to companies listed in the Star (51.9\%) or Standard (37.5\%) segments. The presence of Blue Chips is usually negligible except for 2006 and 2007 when they represent about $20 \%$ of the cases. As previously pointed out analysts' recommendations are reported in all but ten cases $(93.5 \%)$, while consensus recommendation is reported in two thirds of the events only.

The weight of positive ratings based on analysts' recommendations is slightly higher than the one based on the consensus recommendation reported in the column: $69.9 \%$ versus $63.9 \%$. The time distribution of positive advices varies from 57.9\% in 2005 to $72 \%$ in 2007 for the former and from $63 \%$ to $76 \%$ for the latter. In both cases, we observe the highest fraction of positive spin in 2006 and 2007; while the lowest value occurs in 2005 and 2008 for the analysts' recommendations and in 2008 for the consensus' one. The sample includes 17 sectors, none of which exceed, on average, one fourth of the observations. ${ }^{7}$ Not surprisingly, given the structure of the Italian economy, the most recurrent sectors are Industrial Good \& Services (22.7\%), Banks (13\%), Financial Services (11.7\%), and Construction \& Material (10.4\%).

The relevancy, for our purposes, of the distinction between events with positive vs. neutral or negative recommendation asks for analyzing the characteristics of the two groups. Table 2 reports some descriptive statistics concerning the number of analysts mentioned in the column, the firm's size (book value and capitalization), the price-to-book value, the pre-event market adjusted performance and the variability of earning forecasts. The book value and the price-to-book value refer to the date of the most recent financial reports shown in the column. The capitalization is the company's market value as of one week before the event day.

The pre-event performance is the stock return in the 250 trading days ending one week before the event day, net of the market index return over the same period. The variability of the earnings forecasts is the absolute value of the ratio between the forecast range (the highest minus the lowest forecasted earnings) and the average forecasted earnings for the current year at the column's date.

\footnotetext{
${ }^{7}$ The minimum occurs in 2005 with ten sectors and the maximum in 2007/2008 with 13 sectors.
} 
Table 2 - Events by analysts' recommendation: descriptive statistics

\begin{tabular}{|c|c|c|c|c|c|c|}
\hline & Obs & Mean & Median & Min & Max & Std. Dev. \\
\hline \multicolumn{7}{|c|}{ All recommendations } \\
\hline Number of analysts & 154 & 4.80 & 4 & 0 & 18 & 3.08 \\
\hline Size: book value (mln€) & 153 & 379 & 216 & -131 & 2968 & 506 \\
\hline Size: capitalization $(m \ln €)$ & 154 & 684 & 468 & 107 & 4534 & 718 \\
\hline Price-to-book value & 151 & 2.56 & 2.02 & 0.41 & 24.20 & 2.32 \\
\hline Mkt. adj. pre-event stock performance (\%) & 154 & 10.80 & 5.40 & -44.90 & 106.60 & 27.70 \\
\hline Variability of earnings forecasts (\%) & 99 & 58.90 & 20.50 & 0.50 & 1484.00 & 180.80 \\
\hline Variability of earnings forecasts $+1(\%)$ & 99 & 50.70 & 22.30 & 0.60 & 1764.30 & 177.90 \\
\hline \multicolumn{7}{|c|}{ Positive recommendations } \\
\hline Number of analysts & 92 & 5.50 & 5 & 1 & 18 & 2.96 \\
\hline Size: book value $(\mathrm{mln} €)$ & 92 & 245 & 174 & -131 & 848 & 198 \\
\hline Size: capitalization $(\mathrm{mln} €)$ & 92 & 577 & 479 & 116 & 2483 & 386 \\
\hline Price-to-book value & 90 & 2.98 & 2.29 & 0.59 & 24.20 & 2.76 \\
\hline Mkt. adj. pre-event stock performance (\%) & 92 & 12.60 & 7.40 & -44.90 & 83.50 & 28.10 \\
\hline Variability of earnings forecasts (\%) & 69 & 49.90 & 17.60 & 0.50 & 900.00 & 128.60 \\
\hline \multicolumn{7}{|c|}{ Neutral or negative recommendations } \\
\hline Number of analysts & 52 & 4.50 & 4 & 1 & 11 & 2.70 \\
\hline Size: book value $(\mathrm{mln} €)$ & 52 & 536 & 270 & 36 & 2968 & 702 \\
\hline Size: capitalization $(\mathrm{mln} €)$ & 52 & 707 & 435 & 107 & 4534 & 873 \\
\hline Price-to-book value & 52 & 1.94 & 1.53 & 0.41 & 7.54 & 1.30 \\
\hline Mkt. adj. pre-event stock performance (\%) & 52 & 5.30 & 2.60 & -34.80 & 69.60 & 24.00 \\
\hline Variability of earnings forecasts (\%) & 30 & 79.60 & 22.60 & 3.70 & 1484.00 & 266.50 \\
\hline \multicolumn{7}{|c|}{$\begin{array}{l}\text { Equality tests (p-values) } \\
\end{array}$} \\
\hline Number of analysts & & 0.044 & 0.038 & & & \\
\hline Size: book value & & 0.000 & 0.001 & & & \\
\hline Size: capitalization & & 0.221 & 0.438 & & & \\
\hline Price-to-book value & & 0.012 & 0.000 & & & \\
\hline Mkt. adj. pre-event stock performance & & 0.116 & 0.136 & & & \\
\hline Variability of earnings forecasts & & 0.456 & 0.112 & & & \\
\hline
\end{tabular}

Equality tests: t-test for means and Wilcoxon/Mann-Whitney test for medians

The stocks with good analyst's rating have a higher price-to-book ratio and a higher number of equity researches mentioned in the column, with respect to the stocks with a poor rating. Both groups reveal a past over-performance and a medium firm size (capitalization). The first group has a better marked-adjusted performance, a lower dispersion of analysts' forecasts, and a smaller firm size, even if these differences are not statistically significant according to a t-test for means and a 
Wilcoxon/Mann-Whitney test for medians. The book value and the price-to-book value differ significantly between the two groups.

\subsection{Methodology}

The spin of analysts' recommendations is the key variable to investigate the attention-grabbing hypothesis. Each column has a section that synthesises the most recent equity researches covering the "Stock of the Week".

For each column we measure the spin by first converting every single recommendation into a score according to a standard five-point scale. We then compute the average score. ${ }^{8}$ We distinguish between positive and non-positive spins. Non positive spins include both neutral and negative recommendations. In line with previous studies, neutral and negative recommendations cause similar price reactions (Lloyd-Davies and Canes, 1978; Beneish, 1991).

\subsubsection{Abnormal Returns}

To measure the market reaction to our potentially attention-grabbing events, we use a traditional event-study methodology (Brown and Warner, 1980, 1985; Campbell et al., 1997). We use three models for normal returns: (1) the Market Model, (2) the CAPM, and (3) the four-factor model by Carhart (1997). ${ }^{9}$

We consider a 16-day event window $[-5 ;+10]$ and a 250 -day estimation window $[-255 ;-6]$. For each firm $i$ and time $t$, we define the abnormal return as $A R_{i, t}=R_{i, t}-\mathrm{E}\left(R_{i, t} \mid \mathbf{X}_{i, t}\right)$, where $A R_{i, t}, R_{i, t}$ and $\mathrm{E}\left(R_{i, t} \mid \mathbf{X}_{i, t}\right)$ are firm $i$ 's abnormal, actual and normal returns, ${ }^{10}$ respectively. Averaging the abnormal returns $\left(A R_{i, t}\right)$ across firms, we obtain the mean abnormal return at time $t, \overline{A R}_{t}$.

To assess the overall effect of events, we then aggregate the daily mean abnormal returns in the cumulative abnormal return from day $\tau_{1}$ to day $\tau_{2}, \operatorname{CAR}\left(\tau_{1}, \tau_{2}\right)$. To test the statistical significance of our results, we perform both parametric (Boehmer et al., 1991) and non-parametric tests (Wilcoxon test). All our inference results are then double-checked by constructing bootstrap confidence interval.

\footnotetext{
${ }^{8}$ To get the analysts' consensus, we calculated the mean, median and modal score. The results are unaffected by the choice of the central tendency measure we use.

${ }^{9}$ All models lead to similar results. Therefore, we present the results only for the four-factor model.

${ }^{10} \mathrm{We}$ consider excess returns over the risk-free rate.
} 


\subsubsection{Abnormal volumes}

We perform a similar analysis on volumes ${ }^{11}$. Following Ajinkya and Jain (1989), we define the abnormal volume as $A V_{i, t}=V_{i, t}-\mathrm{E}\left(V_{i, t} \mid \mathbf{X}_{i, t}\right)$, where $A V_{i, t}, V_{i, t}$ and $\mathrm{E}\left(V_{i, t} \mid \mathbf{X}_{i, t}\right)$ are security $i$ 's abnormal, actual and normal (logarithmic) volume, respectively. As a model for normal volumes, we regress the volume of each firm $i$ on the volume of the market as a whole. Averaging the abnormal volume across firms, we obtain the mean abnormal volume at time $t, \overline{A V}_{t}$. The statistical significance of our results is tested as in the case of abnormal returns.

\section{Empirical analysis}

\subsection{Abnormal returns and abnormal volumes}

Since the column publication day is always Saturday, our event days are all Mondays. However, after checking for it, we do not detect any "Monday effect" in the period of analysis. ${ }^{12}$

Considering all available cases, we find a significant positive abnormal return of $0.9 \%$ associated to volumes that are $32 \%$ higher than normal at the event day. We also observe an abnormal return on day -1 , i.e. the Friday preceding the publication of the column. Two major reasons can explain the abnormal return on day -1 . Since the column is actually printed on the Thursday night, insiders could trade on the information available in the column. Insiders could be the management of the company covered in the column or the journalist himself. However, we can discard these possibilities given the reputation of the journalist and the strict rules on insider trading for the management of listed companies and journalists in place in Italy. ${ }^{13}$ The alternative explanation could be that concurring events in the days preceding our event date may cause the market reaction, and not the column itself. We consider price-sensitive events by analysing all the press releases, and the newspaper or magazine articles available in the companies' websites in the time window [-1;0], i.e. since the Friday before the event day. ${ }^{14}$ Among potential confounding effects, we check analysts' reports in the same time window since their recommendations could drive investors' decisions and therefore move prices. Taking into account these confounding events, we exclude 34

\footnotetext{
${ }^{11}$ We also repeat all the analysis using the turnover instead of volumes. However, the results remain unaffected.

${ }^{12}$ We inserted a dummy variable equal to one when the day of the week is Monday in our regression analysis. Since the dummy variable is not statistically significant we do not include it in our final regression model reported below.

${ }^{13}$ See the Italian law on financial markets ("Testo Unico della Finanza"). In particular, art. 114 prescribes that companies quoted in regulated stock exchanges, with no delay, have to make inside information publicly available when the information is deemed to be of a precise nature and is likely to significantly influence stock prices. Trading on the ground of inside news is prosecuted by law (art. 184 and art. 187-bis).

${ }^{14}$ We chose this window since we detected abnormal returns in the day preceding our event date, while no abnormal returns were found in the days before that.
} 
observations, and we find that the abnormal return on day -1 disappears, while the one in the event date remains positive and statistically significant and of about the same magnitude $(0.88 \%)$. In this case, volumes are $20 \%$ higher than normal. Considering the 80 cases associated to positive analysts' recommendations and no confounding effects, we find a higher abnormal return (1.16\%) and volumes that are about $36 \%$ higher than normal. Instead, there are no statistically significant abnormal returns or abnormal volumes in the occurrences associated with negative grades in absence of confounding events. This evidence seems in line with the AGH that predicts positive and significant abnormal returns and volumes for positive recommendations and insignificant abnormal returns and volumes for negative recommendations. These results are summarized by figure 1 and table 3 .

Fig. 1 - Abnormal Returns around the event day (no confounding effects)
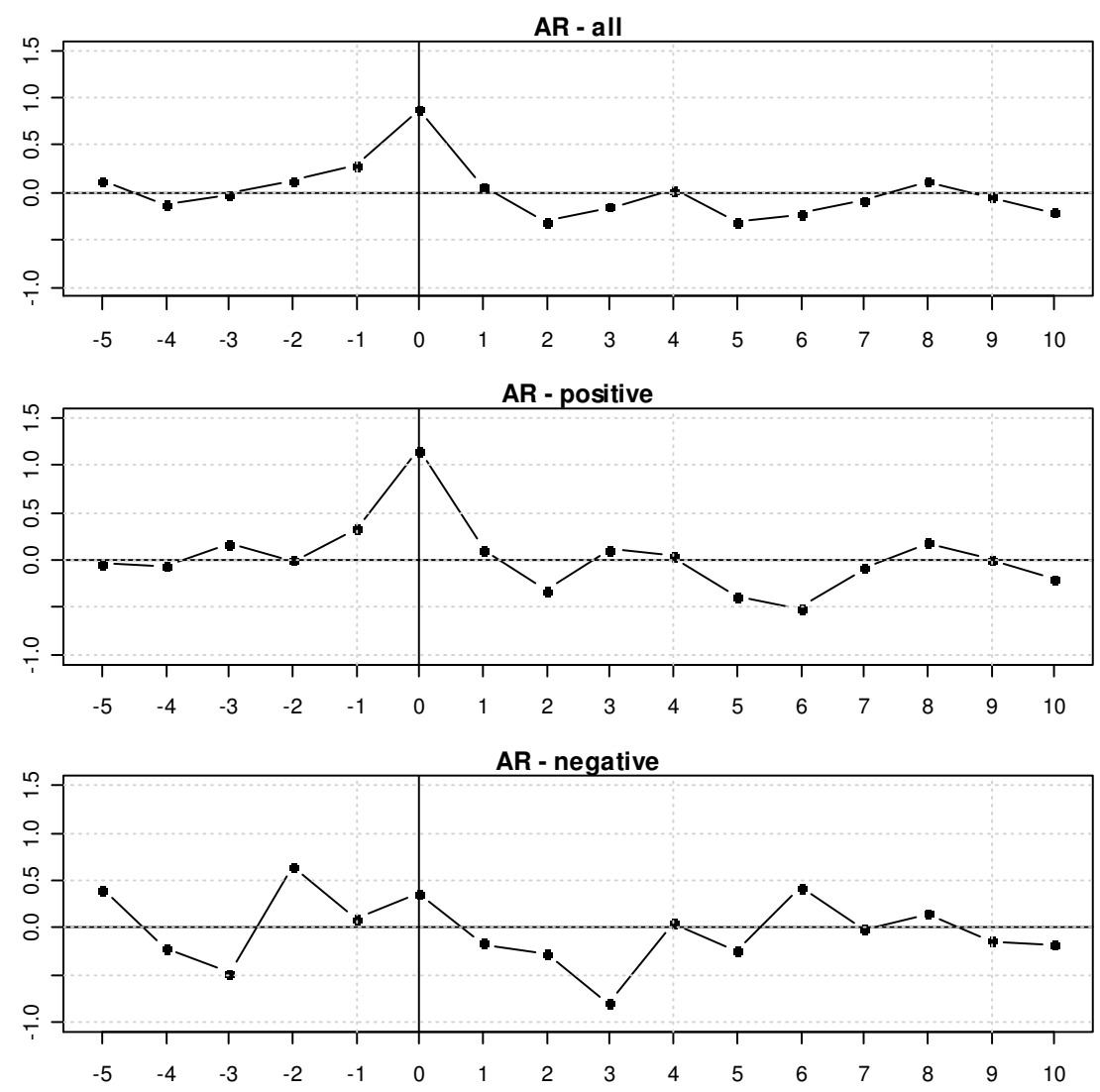

Table 3 shows also the pre-event and post-event Cumulative Abnormal Returns (CARs) for positively and negatively recommended stocks, respectively in Panel A and B. We distinguish between the two cases (positive and negative recommendations) to test the AGH because of the asymmetric market reaction. Even if in the tables we consider the sample with no confounding 
events, we also check the CARs in the pre-event window $[-5 ;-1]$, to verify that we eliminated all potential confounding effects. All tests (t-stat, Wilcoxon V-stat and bootstrap confidence intervals) reveal that pre-event CARs in both cases are not statistically significant. Then, we verify if the initial market reaction at the event day is eventually reverted in the following two weeks to test IDH vs. PPT. For the positively recommended stocks (Table 3 - Panel A), we observe a reduction in CARs in the days following the event day. CARs are still positive but not statistically significant. According to the Wilcoxon test, the only exception is a slightly statistically significant CAR $(+0.7 \%)$ in the window $[0 ;+5]$. It could be that the negative abnormal returns in the first days following the event day are not enough to reverse the initial attention-grabbing effect in the first week of trading. However, it eventually disappears since the CAR in the window $[0 ;+10]$ is not statistically different from zero, i.e. we observe a complete reversal of the positive AR on the event day. These results are in line with the PPH: the column seems not to convey any value to investors, but only to initially attract their attention.

Table 3 - CARs for the positively (Panel A) and negatively (Panel B) recommended stocks

\begin{tabular}{|c|c|c|c|c|c|c|c|c|}
\hline & $\begin{array}{l}\text { CAR } \\
(\%)\end{array}$ & t-stat & p-value Sign. & $\begin{array}{c}\text { Lower } \\
\text { CI }\end{array}$ & $\begin{array}{cc}\text { Upper } & \text { Sign. } \\
\text { CI } & \end{array}$ & V-stat & p-value & Sign. \\
\hline \multicolumn{9}{|c|}{ Panel A: Positive Rating - No Confounding Effects $($ No. Obs. $=80)$} \\
\hline Pre-event $[-5 ;-1]$ & 0.42 & 0.99 & 0.326 & -0.005 & 0.012 & 1925 & 0.144 & \\
\hline AR Event day [0] & 1.16 & 4.05 & 0.000 & 0.006 & 0.017 & 2430 & 0.000 & $* * *$ \\
\hline Post-event $[0 ;+5]$ & 0.70 & 1 & 0.321 & -0.007 & 0.020 & 2090 & 0.024 & $*$ \\
\hline Post-event $[0 ;+10]$ & 0.08 & 0.1 & 0.921 & -0.016 & 0.016 & 1816 & 0.348 & \\
\hline \multicolumn{9}{|c|}{ Panel B: Negative Rating - No Confounding Effects (No. Obs. = 35) } \\
\hline Pre-event $[-5 ;-1]$ & 0.44 & 0.64 & 0.527 & -0.009 & 0.018 & 338 & 0.716 & \\
\hline AR Event day [0] & 0.36 & 1.17 & 0.250 & -0.002 & 0.010 & 365 & 0.422 & \\
\hline Post-event $[0 ;+5]$ & -1.08 & -1.68 & 0.102 & -0.023 & 0.001 & 224 & 0.140 & \\
\hline Post-event $[0 ;+10]$ & -0.85 & -0.7 & 0.490 & -0.030 & 0.017 & 183 & 0.030 & $*$ \\
\hline
\end{tabular}

$* * *, * *$, and $*$ indicate statistically significant at $0.01,0.05,0.1$ level respectively.

The table reports the t-test, $95 \%$ bootstrap confidence intervals and non-parametric Wilcoxon V-stat.

The case of negatively recommended stocks (Table 3 - Panel B) is peculiar since we do not find any abnormal returns either at the event day or in the following two trading weeks ${ }^{15}$. It seems that the only positively recommended stocks are able to attract investors' attention as the AGH predicts. In the literature, just Lidén (2007) and Sant and Zaman (1996) document a similar asymmetric price

\footnotetext{
${ }^{15}$ According to the Wilcoxon V-stat, we only find a slightly significant negative CAR in the window $[0 ;+10]$.
} 
reaction in the publication day, though in the latter case the negatively recommended stocks experience a significant price decline on day +1 .

\subsection{Regression analysis of abnormal returns and volumes}

In the previous section, we detect a market reaction at the event day in case of positively recommended stocks. In this section, we investigate the potential determinants of this market reaction through regression analysis. In particular, we propose two regression models: one for abnormal returns and one for abnormal volumes. We concentrate only on positively recommended stocks, since we do not detect any market reaction for negatively recommended stocks. ${ }^{16}$

Among the covariates that could explain ARs and AVs, we consider several variables: the number of analysts mentioned in the column; the pre-event market adjusted stock performance; the presence of earning forecasts in the column; the firm's size (natural logarithm of market capitalization); the price-to-book value; the presence of any confounding effect; the industry of the stock; the year of the column.

Since we use a four-factor model to detect abnormal returns, previous performances, size and priceto-book variables should indirectly be already taken into account by the four factors and we should not find any statistically significant effect associated to these variables in our regression for abnormal returns. Indeed, we find that these variables are not statistically significant. ${ }^{17}$ For this reason, in table 4, we present the final - reduced - version of our regression model, only including the economic relevant explanatory variables (i.e. number of analysts; presence of earnings forecast, confounding effects, industry and year).

Before commenting the results, we observe that our specification tests do not reject the two models at all conventional level of significance. ${ }^{18}$

After controlling for contextual confounding effects, industry and year effect, we focus on the two main variables of the regression: number of analysts and presence of earnings forecasts. The number of analysts cited in the column has a positive and significant coefficient in both regressions. Since we are dealing with an attention-grabbing event, this result is in line with economic theory. The number of analysts may be considered at the same time as a proxy for the popularity enjoyed

\footnotetext{
${ }^{16}$ Since ARs and AVs of negatively recommended stocks are not statistically different from zero, the dependent variable would be a "vector of zeros".

${ }^{17}$ These variables are not significant also for AVs, thus we exclude them from the AV regression.

${ }^{18}$ We consider the Reset general specification test, the Breush-Pagan heteroscedasticity test, and the Shapito-Wilk normality test. The latter test rejects the hypothesis of normality for the AR model. Thus, given the reduced number of observation, caution is needed in making inferences from this model.
} 
by the company in the investors' community and for the information set available to the market. If the column conveyed new information, more information available on the market (i.e., more analysts following) would result in smaller ARs (negative coefficient). Instead, since the columns simply attract the attention of investors with no additional new information, it is natural to observe a greater reaction (positive coefficient) for the most "glamour" stocks (i.e., the stocks analysts follow mostly). It is worth mentioning that Sant and Zaman (1996), though presenting an asymmetric reaction as well, find an opposite result with respect to the relation with the number of analysts: in their study, the positive abnormal market reaction at the time of the distribution of Business Week interests only the stocks followed by less than twenty analysts (ten for reports with analyst as a source), and the stocks of this group show a price reaction that increases as the number of analysts decreases. Our results support the evidence in Fehle, Tsyplakov and Zdorovtsov (2005) of a positive relation between the price reaction and the firm's notoriety.

Table 4 - Regressions for Ars and Avs and positively and negatively recommended stocks

\begin{tabular}{|c|c|c|c|c|c|c|}
\hline \multirow[b]{2}{*}{ Regression } & \multicolumn{3}{|c|}{$\begin{array}{c}\text { AR Positive } \\
\text { Recommendations }\end{array}$} & \multicolumn{3}{|c|}{$\begin{array}{c}\text { AV Positive } \\
\text { Recommendations }\end{array}$} \\
\hline & Coeff. & S.E. & Sign. & Coeff. & S.E. & Sign. \\
\hline Intercept & 0.00 & 1.36 & & 0.22 & 0.49 & \\
\hline N. Analysts & 0.27 & 0.14 & $*$ & 0.09 & 0.05 & $*$ \\
\hline Earnings Forecast & -1.64 & 0.86 & $*$ & -0.43 & 0.31 & \\
\hline Confounding Effect & 0.59 & 0.90 & & 0.57 & 0.33 & $*$ \\
\hline Joint Effects & & Stat. & Sign. & & Stat. & Sign. \\
\hline Industry effect & $\mathrm{F}(13,65)$ & 0.89 & & $\mathrm{~F}(13,65)$ & 0.74 & \\
\hline Year effect & $\mathrm{F}(4,65)$ & 2.17 & $*$ & $\mathrm{~F}(4,65)$ & 0.84 & \\
\hline Multiple R-squared & 0.27 & & & 0.27 & & \\
\hline $\mathrm{N}$ & 86 & & & 86 & & \\
\hline Diagnostic & & Stat. & Sign. & & Stat. & Sign. \\
\hline Reset test & & 0.59 & & & 0.09 & \\
\hline Breusch-Pagan test & & 18.37 & & & 20.99 & \\
\hline Shapiro-Wilk test & & 0.97 & $*$ & & 0.98 & \\
\hline
\end{tabular}

Instead, the presence of earnings forecast reduces abnormal returns and has no effect on abnormal volumes. To understand the negative effect on ARs, it is useful to evidence that when earnings forecasts are available in one column, then also the consensus recommendation is available. Thus, the technical level and the number of information available in the column increase when earnings 
forecasts are available. Since the attention-grabbing effect has an emotional nature, it is clear that numerous and technical information increases the complexity of the column thus lowering the attention-grabbing effect.

\section{Conclusion}

This paper deals with a long standing issue in finance: weather the market reaction to second-hand information is due to price pressure or dissemination. We take an attention-grabbing perspective (Barber and Odean, 2008) as a particular form of price pressure. More precisely, we argue that if the market reaction has an attention-grabbing motivation the publication of positive recommendations should induce a significant increase in prices and volume of trading, while the publication of negative or neutral recommendations should have no effects. This emotional price reaction on the event day is also expected to revert in the post-event period. Our evidence supports both predictions. The attention-grabbing theory allows to predict an asymmetric market reaction, already detected in few other empirical studies, otherwise difficult to rationalize within the standard price pressure hypothesis.

Contrary to the available evidence, we document a positive relation between the number of analysts quoted in the column and the price (volume) increase. Since we are dealing with an attentiongrabbing event, this result is in line with economic theory. The number of analysts may be considered at the same time as a proxy for the popularity enjoyed by the company in the investors' community and for the information set available to the market. If the column conveyed new information, more information available on the market (i.e. more analysts following) would result in smaller abnormal returns. Instead, since the columns simply attract the attention of investors with no additional new information, it is natural to observe a greater reaction for the most "glamour" stocks (i.e. the stocks analysts follow mostly).

To the best of our knowledge, this paper is the first one looking at the stock price reaction to the dissemination of analysts' recommendations through printed media from an attention-grabbing perspective. In particular, we contribute to the literature proposing and testing the hypothesis of an asymmetric price reaction. These elements differentiate our paper to others that test the attentiongrabbing theory referring to different types of events. 


\section{References}

Ajinkya B. and P. Jain (1989) "The behavior of daily stock market trading volume", Journal of Accounting and Economics, 11, 331-359.

Albert, Jr. R. and T. Smaby (1996) "Market Response to Analyst Recommendations in the 'Dartboard' Column: The Information and Price-Pressure Effects', Review of Financial Economics, Winter, 59-74.

Beneish, Messod D. (1991) "Stock Prices and the Dissemination of Analysts' Recommendations", Journal of Business, 64 (3), July, 393-416.

Barber, Brad M. and D. Loeffler (1993) "The "Dartboard" Column: Second-Hand Information and Price Pressure”, Journal of Financial and Quantitative Analysis, 28 (June), 273-284.

Barber, Brad M. and Terrance Odean (2008) "All That Glitters: The Effect of Attention and News on the Buying Behavior of Individual and Institutional Investors", The Review of Financial Studies, 21(2), 785-818.

Boehmer E., J. Musumeci and A.B. Poulsen (1991) "Event-Study Methodology Under Conditions of Event-Induced Variance”, Journal of Financial Economics, 30, 253-272.

Brown S. and J. Warner (1980) "Measuring security price performance", Journal of Financial Economics, 8, 205-258.

Brown S. and J. Warner (1985) "Using daily stock returns. The case of event studies", Journal of Financial Economics, 14, 3-31.

Campbell, J.Y., A.C. MacKinlay and A.W Lo (1997) The econometrics of financial markets, Princeton, Princeton University Press.

Carhart, M.M. (1997) “On Persistence in Mutual Fund Performance”, The Journal of Finance, 52 (1), 57-82.

Desai, Hemang, and Prem C. Jain (1995) “An Analysis of the Recommendations of the 'Superstar' Money Managers at Barron's Annual Roundtable”, Journal of Finance, 50 (4), September, $1257-$ 73.

Desai, Hemang, Bing Liang, and Ajai K. Singh (2000) "Do All-Stars Shine? Evaluation of Analyst Recommendations”, Financial Analysts Journal, 56 (3), May/June, 20.

Felettigh A. e Paola Monti (2008) "How to interpret the CPIS data on the distribution of foreign portfolio assets in the presence of sizeable cross-border positions in mutual funds. Evidence for Italy and the main euro-area countries", in Questioni di Economia e Finanza, Banca d'Italia, n. 16, August. 
Fehle, Frank, Sergey Tsyplakov and Vladimir Zdorovtsov (2005) "Can Companies Influence Investor Behaviour through Advertising? Super Bowl Commercials and Stock Returns", European Financial Management, 11(5), 625-647.

Ferreira, Eurico J. and Smith Stanley D. (1999) "Stock Price Reactions to Recommendations in the Wall Street journal "Small Stock Focus" Column”, Quarterly Review of Economics and Finance, 39 (3), Fall, 379-389.

Ferreira, Eurico J. and Smith Stanley D. (2003) "Wall \$treet Week": Information or Entertainment?", Financial Analyst Journal, January/February, 45-53.

Odean, Terrance (1999) "Do investors trade too much?”, American Economic Review, 89(5), 127998.

Kiymaz, Halil (2002) "The stock market rumors and stock prices: a test of price pressure and size effect in an emerging market", Applied Financial Economics, 12, 469-474.

Lee, Jevons Chi-wen (1986) "Information content of financial columns", Journal of Economics and Business, 38, 27-39.

Liang, Bing (1999) “Price Pressure: Evidence from the 'Dartboard' Column”, Journal of Business, 72 (1), January, 119-134.

Lidén, Erik R. (2007) “Swedish Stock Recommendations: Information Content or Price Pressure?”, Multinational Finance Journal, 11 (3/4), 253-285.

Liu, Pu, Stanley D. Smith, and Azmat A. Syed (1990) "Stock Price Reactions to the Wall Street Journal's Securities Recommendations", Journal of Financial and Quantitative Analysis, 25 (September), 399-410.

Liu, Pu, Stanley D. Smith, and Azmat A. Syed (1992) "The impact of insider trading scandal on the information content of the Wall Street Journal's 'Heard on the Street' column", Journal of Financial Research, 15 (Summer), 181-188.

Lloyd-Davies, P., and M. Canes (1978), "Stock Prices and the Publication of Second-Hand Information”, Journal of Business, 51 (1), January, 43-56.

Mathur, Ike, and Amjad Waheed (1995) "Stock Price Reactions to Securities Recommended in Business Week’s ‘Inside Wall Street”’, Financial Review, 30 (3), August, 583-604.

Metcalf, Gilbert E. and Burton G. Malkiel (1994) “The Wall Street Journal contests: the experts, the darts, and the efficient market hypothesis”, Journal Applied Financial Economics, 4 (5), October, 371-374.

Muradoğlu, Gülnur and Bilgehan Yazici (2002), “Dissemination of Stock Recommendations and Small Investors: Who Benefits", Multinational Finance Journal, 6 (1), 29-42. 
Odean, Terrance (1999), “Do investors trade too much?”, American Economic Review, 1279-98.

Palmon, O., H-L Sun, A.P. Tang (1994) “The impact of publication of analysts' recommendations on returns and trading volumes", The Financial Review, 29 (August), 395-417.

Palmon, Dan, Ephraim F. Sudit, Ari Yezegel (2009), “The value of columnists' stock recommendations: an event study approach", Review of Quantitative Finance and Accounting, 33, 209-232.

Pettengill, Glenn N., and John M. Clark (2001) "Estimating expected returns in an event study framework: Evidence from the Dartboard column", Quarterly Journal of Business and Economics, 40, 3-21.

Pari, R. A. (1987) “Wall \$treet Week Recommendations: Yes or No?”, Journal of Portfolio Management, 13, 74-76.

Pound, John and Richard Zeckhouser (1990) "Clearly Heard on the Street: the effect of takeover rumors on stock prices", Journal of Business, 63 (July), 291-308.

Pruitt, S. W., Bonnie F. Van Ness, and Robert A. Van Ness (2000) "Clientele Trading in Response to Published information: Evidence from the Dartboard Column", The Journal of Financial Research, Spring, 1-12.

Sant, Rajiv, and Mir A. Zaman (1996) "Market Reaction to Business Week 'Inside Wall Street' Column: A Self-Fulfilling Prophecy”, Journal of Banking and Finance, 20 (4), May, 617-643.

Seasholes, Mark, and Guojun Wu (2004) "Profiting from predictability: Smart traders, daily price limits, and investor attention", SSRN working paper: $\underline{\text { http://ssrn.com/abstract=527182. }}$.

Syed, Azmat A., Pu Liu, and Stanley D. Smith (1989) "The Exploitation of Inside Information at the Wall Street Journal - A Test of Strong Form Efficiency”, Financial Review, 24 (4), November, 567-579.

Trahan, E.A and P.J. Bolster (1995) "The impact of Barron's recommendations on stock prices", Quarterly Journal of Business and Economics, 34 (Autumn), 3-15.

Tversky, Amos and Daniel Kahneman (1974) "Judgment under uncertainty: Heuristics and biases", Science, 185 (4157): 1124-1131.

Wijmenga, R.T. (1990) “The performance of published Dutch stock recommendations”, Journal of Banking and Finance, 14, 559-581.

Wright, D. W. (1994) "Can prices be trusted? A test of the ability of experts to outperform or influence the market", Journal of Accounting, Auditing and Finance, 9 (Spring), 307-23. 


\section{Appendix}

Table A.1 - Event studies regarding explicit or implicit analysts' recommendations published in printed media (Information Dissemination Hypothesis)

\begin{tabular}{|c|c|c|c|c|c|c|c|c|c|c|c|}
\hline \multirow{4}{*}{$\begin{array}{l}\text { Empirical study } \\
\text { Lloyd-Davies and Canes (1978) }\end{array}$} & \multirow{4}{*}{$\begin{array}{c}\text { Newspaper / Magazine } \\
\text { Wall Street Journal (N) }\end{array}$} & \multirow{2}{*}{\multicolumn{2}{|c|}{ Column / Frequency }} & \multirow{4}{*}{\begin{tabular}{c|} 
Period \\
$1970-71$
\end{tabular}} & \multicolumn{2}{|c|}{ Recommendations } & \multirow{2}{*}{\multicolumn{2}{|c|}{$\operatorname{AR}(t=0)$}} & \multicolumn{2}{|c|}{ AR reversal } & \multirow{3}{*}{$\begin{array}{c}\mathrm{AV}(\mathrm{t}=\mathbf{0}) \\
- \\
\end{array}$} \\
\hline & & & & & \multirow{2}{*}{$\begin{array}{l}\text { No } \\
597 \\
\end{array}$} & \multirow{2}{*}{$\begin{array}{c}\text { Type } \\
\text { Buy } \\
\end{array}$} & & & \multirow{2}{*}{\begin{tabular}{|c|} 
Short \\
No \\
\end{tabular}} & \multirow{2}{*}{$\begin{array}{c}\text { Long } \\
- \\
\end{array}$} & \\
\hline & & Herd on the Street & Daily & & & & Yes & $+0,92 \%$ & & & \\
\hline & & Hetu on tile StIEet & Dany & & 188 & Sell & Yes & $-2,37 \%$ & No & - & - \\
\hline Syed et al. (1989) & Wall Street Journal (N) & Herd on the Street & Daily & 1983-84 & 16 & Buy* & Yes & $+0,98 \%$ & No & - & - \\
\hline Pound and Zeckhouser (1990) & Wall Street Journal (N) & Herd on the Street & Daily & $1983-85$ & 42 & Takeover rumours & No & $+0,07 \%$ & No & No & - \\
\hline \multirow{2}{*}{ Liu et al. (1990) } & \multirow{2}{*}{ Wall Street Journal (N) } & \multirow{2}{*}{ Herd on the Street } & \multirow{2}{*}{ Daily } & \multirow{2}{*}{$1982-85$} & 566 & Buy & Yes & $+1,54 \%$ & Partial & - & Yes \\
\hline & & & & & 286 & Sell & Yes & $-1,99 \%$ & No & - & Yes \\
\hline \multirow{2}{*}{ Beneish (1991) } & \multirow{2}{*}{ Wall Street Journal (N) } & \multirow{2}{*}{ Herd on the Street } & \multirow{2}{*}{ Daily } & \multirow{2}{*}{$1978-79$} & 286 & Buy & Yes & $+1,01 \%$ & No & - & - \\
\hline & & & & & 118 & Sell & Yes & $-1,00 \%$ & No & - & - \\
\hline \multirow{4}{*}{ Liu et al. (1992) } & \multirow{4}{*}{ Wall Street Journal (N) } & \multirow{4}{*}{ Herd on the Street } & \multirow{4}{*}{ Daily } & $1982-84$ & 332 & Buy & Yes & $+1,87 \%$ & Partial & - & Yes \\
\hline & & & & $1982-84$ & 172 & Sell & Yes & $-2,30 \%$ & No & - & Yes \\
\hline & & & & $1984-85$ & 234 & Buy & Yes & $+1,09 \%$ & No & - & Yes \\
\hline & & & & 1984-85 & 114 & Sell & Yes & $-1,53 \%$ & No & - & Yes \\
\hline Barber and Loeffler (1993) & Wall Street Journal (N) & Dartboard & Monthly & $1988-90$ & 95 & Buy* & Yes & $+3,53 \%$ & Partial & - & Yes \\
\hline \multirow{2}{*}{ Palmon et al. (1994) } & \multirow{2}{*}{ Business week (M) } & \multirow{2}{*}{ Inside Wall Street } & \multirow{2}{*}{ Weekly } & \multirow{2}{*}{ 1983-89 } & 280 & Buy & Yes & $+1,91 \%$ & No & - & Yes \\
\hline & & & & & 49 & Sell & Yes & $-0,67 \%$ & No & - & No \\
\hline \multirow{2}{*}{ Desai and Jain (1995) } & Barron's (M) & Annual Roundtable & & 1068_01 & 1559 & Buy & Yes & $+1,04 \%$ & No & No & - \\
\hline & Barron s (M) & Annual Roundtable & Annual & $1908-91$ & 152 & Sell & Yes & $-1,16 \%$ & No & No & - \\
\hline Albert and Smaby (1996) & Wall Street Journal $(\mathrm{N})$ & Dartboard & Monthly & $1988-91$ & 140 & Buy & Yes & $+3,21 \%$ & No & No & Yes \\
\hline Desai et al. (2000) & Wall Street Journal (N) & All-Star Analyst Survey & Annual & $1993-96$ & 1157 & Buy & Yes & $+0,42 \%$ & No & No & - \\
\hline Pettengill and Clark (2001) & Wall Street Journal (N) & Dartboard & Monthly & $1990-99$ & 446 & Buy* & Yes & $+2,77 \%$ & No & Partial & - \\
\hline $\begin{array}{l}\wedge \text { Editor's and analysts' recomme } \\
* \text { Including sell recommendation } \\
{ }^{\circ} \text { Three-day period (from }-1 \text { to + } \\
\text { Yes = statistically significant }\end{array}$ & $\begin{array}{l}\text { ons } \\
\text { study reverses the sign }\end{array}$ & ARs for these securi & & & & & & & & & \\
\hline
\end{tabular}


Table A.2 - Event studies regarding explicit or implicit analysts' recommendations published in printed media (Price Pressure Hypothesis)

\begin{tabular}{|c|c|c|c|c|c|c|c|c|c|c|c|}
\hline \multirow{3}{*}{$\begin{array}{l}\text { Empirical study } \\
\text { Wijmenga (1990) }\end{array}$} & \multirow{3}{*}{$\begin{array}{l}\text { Newspaper / Magazine } \\
\text { Elseviers Magazine (M) } \\
\text { Beleggers Belangen }(\mathrm{M}) \\
\text { de Financiele Koerier }(\mathrm{M})\end{array}$} & \multirow{2}{*}{\multicolumn{2}{|c|}{ Column / Frequency }} & \multirow{3}{*}{$\begin{array}{l}\text { Period } \\
1978-83\end{array}$} & \multicolumn{2}{|c|}{ Recommendations } & \multirow{2}{*}{\multicolumn{2}{|c|}{$\operatorname{AR}(t=0)$}} & \multicolumn{2}{|c|}{ AR reversal } & \multirow{3}{*}{$\begin{array}{c}\mathbf{A V}(\mathbf{t}=\mathbf{0}) \\
-\end{array}$} \\
\hline & & & & & \multirow{2}{*}{$\begin{array}{l}\text { No } \\
329\end{array}$} & \multirow{2}{*}{$\begin{array}{l}\text { Type } \\
\text { Buy }\end{array}$} & & & \multirow{2}{*}{ Short } & \multirow{2}{*}{$\begin{array}{l}\text { Long } \\
\text { Yes }\end{array}$} & \\
\hline & & & Weekly & & & & Yes & - & & & \\
\hline Metcalf and Malkiel (1994) & Wall Street Journal (N) & Dartboard & Monthly & $1990-92$ & 120 & Buy & Yes & $+3,24 \%$ & - & Yes & - \\
\hline Wright (1994) & Wall Street Journal (N) & Dartboard & Monthly & & & & Yes & & & & \\
\hline \multirow[t]{2}{*}{ Trahan and Bolster (1995) } & \multirow[t]{2}{*}{ Barron's (M) } & \multirow{2}{*}{$\begin{array}{l}\text { Up and Down Wall } \\
\text { Street, Investment News } \\
\text { and Views }\end{array}$} & \multirow[t]{2}{*}{ Weekly } & \multirow[t]{2}{*}{1988} & 144 & Buy $^{\wedge}$ & Yes & $+2,10 \%$ & Yes & Yes & - \\
\hline & & & & & 11 & Sell & Yes & $-0,93 \%$ & - & - & - \\
\hline Mathur and Waheed (1995) & Business week (M) & Inside Wall Street & Weekly & 1981-89 & 233 & Buy & Yes & $+1,71 \%$ & - & Yes & Yes \\
\hline Sant and Zaman (1996) & Business week (M) & Inside Wall Street & Weekly & $1976-88$ & 328 & Buy & Yes & $+1,16 \%$ & No & Yes & Yes \\
\hline Sant and Zaman (1996) & Business week (M) & Inside Wall Street & Weekly & $1976-88$ & 40 & Sell & No & $-0,25 \%$ & No & No & - \\
\hline Liang (1999) & Wall Street Journal (N) & Dartboard & Monthly & $1990-94$ & 216 & Buy* & Yes & $+2,84 \%$ & Yes & Yes & Yes \\
\hline Pruit et al. (2000) & Wall Street Journal (N) & Dartboard & Monthly & 1994-95 & 92 & Buy & Yes & $+3,46 \%$ & No & - & Yes \\
\hline \multirow{2}{*}{ Lidén (2007) } & \multirow{2}{*}{ Six Swidish $\mathrm{M}$ and $\mathrm{N}$} & & & \multirow{2}{*}{$1995-00$} & 566 & Buy & Yes & $+0,37 \%$ & Yes & Yes & Yes \\
\hline & & & $\begin{array}{l}\text { Weekly, } \\
\text { Monthly }\end{array}$ & & 42 & Sell & No & $-0,36 \%$ & No & No & No \\
\hline Palmon et al. (2009) & Business week (M) & Inside Wall Street & Weekly & $2002-03$ & 551 & Buy & Yes & $+4.61 \%^{\circ}$ & Yes & Yes & Yes \\
\hline \multicolumn{12}{|c|}{$\begin{array}{l}\text { ^ Editor's and analysts' recommendations } \\
\text { * Including sell recommendations (the study reverses the sign of the ARs for these securities) } \\
\text { - Three-day period (from }-1 \text { to }+1 \text { ) } \\
\text { Yes = statistically significant }\end{array}$} \\
\hline
\end{tabular}

